\title{
PHYSIOLOGICAL FACTORS AFFECTING PERFORMANCE IN ELITE DISTANCE RUNNERS
}

\author{
Leif Inge Tjelta, Shaher A. I. Shalfawi \\ Department of Education and Sports Science, \\ University of Stavanger, Stavanger, Norway
}

\begin{abstract}
Running distances from $3000 \mathrm{~m}$ to the marathon (42 $195 \mathrm{~m})$ are events dominated by energy contribution of the aerobic energy system. The physiological factors that underlie success in these running events are maximal oxygen uptake $\left(\mathrm{VO}_{2 \max }\right)$, running economy $(\mathrm{RE})$, the utilization of the maximum oxygen uptake $\left(\% \mathrm{VO}_{2 \max }\right)$ and velocity at the anaerobic threshold (vAT). $\mathrm{VO}_{2 \max }$ for distance runners competing on an international level has been between 70 and $87 \mathrm{ml} / \mathrm{kg} / \mathrm{min}$ in men, and between 60 and $78.7 \mathrm{ml} / \mathrm{kg} / \mathrm{min}$ in women, respectively. Due to lack of air resistance, laboratory testing of RE and vAT are recommended to be conducted on treadmill with $1 \%$ slope. $\% \mathrm{VO}_{2 \max }$ are in most studies expressed as the average fractional utilization of $\mathrm{VO}_{2 \max }$ at vAT. Much of the current understanding regarding the response to exercise is based on studies of untrained and moderately trained individuals. To use this knowledge to give training recommendations to elite runners is hardly valid. Researchers should therefore exercise caution when giving training recommendations to coaches and elite distance runners based on limited available research.
\end{abstract}

Keywords: $\mathrm{VO}_{2 m a x}$; running economy; anaerobic threshold

\section{INTRODUCTION}

Long distances from $3000 \mathrm{~m}$ to the marathon $(42195 \mathrm{~m})$ are events dominated by energy contribution of the aerobic energy system [10, 64]. Improving performance over these distances has to influence one or more of the physiological factors that underlie success in distance running. Studies 
have shown that these physiological factors are maximal oxygen uptake $\left(\mathrm{VO}_{2 \max }\right)[21,25,49]$, running economy (RE) [12, 44, 49], utilization of the maximal oxygen uptake $\left(\% \mathrm{VO}_{2 \max }\right)[1,47]$ and velocity at the anaerobic threshold (vAT).

This brief review is concerned with the available evidence with respect to $\mathrm{VO}_{2 \max }, \mathrm{RE}, \% \mathrm{VO}_{2 \max }$ and $\mathrm{vAT}$ in elite distance runners.

\section{MAXIMUM OXYGEN UPTAKE ( $\left.\mathrm{VO}_{2 M A X}\right)$}

A high $\mathrm{VO}_{2 \max }$ is a prerequisite for success in distance running [16, 34, 41, 58]. Legaz-Arrese et al. [35] examined the relationship between $\mathrm{VO}_{2 \max }$ and running distances in Spanish elite runners. The study included 190 runners (137 men and 53 women) who competed at national and international level in distances from $100 \mathrm{~m}$ to the marathon. The runners' $\mathrm{VO}_{2 \max }$ increased with increasing competition distance from $100 \mathrm{~m}$ to $3000 \mathrm{~m}$. Among runners who competed in distances from $3000 \mathrm{~m}$ to the marathon, the variations in $\mathrm{VO}_{2 \max }$ were small. The authors concluded that a high $\mathrm{VO}_{2 \max }$ is necessary to perform at national and international level in race distances from $3000 \mathrm{~m}$ to the marathon [35]. However, substantial variation in $\mathrm{VO}_{2 \max }$ has also been found among runners who are of the same performance level and who compete over the same distances $[12,26,59,68]$.

A study of Spanish elite male middle- and long-distance runners between 2000 and 2008, shows following average $\mathrm{VO}_{2 \max }$ values [54]. $1500 \mathrm{~m}(\mathrm{n}=23)$ $67.4 \pm 4.7 \mathrm{ml} / \mathrm{kg} / \mathrm{min}, 5000 \mathrm{~m}(\mathrm{n}=20) 71.4 \pm 3.9 \mathrm{ml} / \mathrm{kg} / \mathrm{min}$ and $10000 \mathrm{~m}$ $(\mathrm{n}=12) 71.8 \pm 6.7 \mathrm{ml} / \mathrm{kg} / \mathrm{min}$. The runners were tested at the start of the training year as part of a screening process.

A study by Legaz-Arrese et al. [34] showed that there was no significant difference in $\mathrm{VO}_{2 \max }$ between ten marathon runners and eight $3000 \mathrm{~m}$ steeplechase runners at the same relative level of performance. The marathon runners (average time for the marathon 2:12.04) and the $3000 \mathrm{~m}$ the steeplechase runners (average best times of $8: 37.83$ ) had $81.3 \pm 4.0$ and $80.5 \pm 3.9 \mathrm{ml} / \mathrm{kg} / \mathrm{min}$ in $\mathrm{VO}_{2 \max }$, respectively.

The Nordic male record holder for the $5000 \mathrm{~m}$, at the time writing, had a $\mathrm{VO}_{2 \max }$ of $86.7 \mathrm{ml} / \mathrm{kg} / \mathrm{min}$ at the age of 21 [68]. $\mathrm{VO}_{2 \max }$ values of elite Kenyan runners who were tested by Billat et al. [5] in 2002 and who used a training regimen based on moderate training volume and rather high intensity were: men $(\mathrm{n}=6): 78.4 \pm 2.1 \mathrm{ml} / \mathrm{kg} / \mathrm{min}$, and women $(\mathrm{n}=6): 68.6 \pm 1.1 \mathrm{ml} / \mathrm{kg} / \mathrm{min}$. These athletes ran $158 \pm 19 \mathrm{~km} /$ week (men) and $127 \pm 8 \mathrm{~km} /$ week (women). Average time for $10000 \mathrm{~m}$ was 28:15 min $( \pm 15 \mathrm{~s})$ for men and 32:22 min 
$( \pm 35 \mathrm{~s})$ for women. Men $(\mathrm{n}=7)$ who used a training regimen consisting of higher training volume $(174 \pm 17 \mathrm{~km} /$ week $)$ and somewhat lower training intensity had a slightly lower average $\mathrm{VO}_{2 \max }(74.7 \pm 2.6 \mathrm{ml} / \mathrm{kg} / \mathrm{min})$ than the runners who trained more intensively. These runners also performed a little

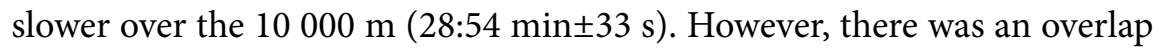
in $\mathrm{VO}_{2 \max }$ and performance level among the runners in the two groups.

The outstanding Norwegian female distance runner Grete Waitz who won the World Cross Country Championships five times (1978-81 and 1983 ) and New York Marathon nine times (1978-1980, 1982-86 and 1988) had, early in her career, a $\mathrm{VO}_{2 \max }$ of $73 \mathrm{ml} / \mathrm{kg} / \mathrm{min}$ [14]. The female world marathon record holder at time of writing, Paula Radcliffe, measured $70 \mathrm{ml} / \mathrm{kg} / \mathrm{min}$ in $\mathrm{VO}_{2 \max }$ in 2003, the year she set her world record time of 2:15:25 [28].

Norwegian female distance runners $(\mathrm{n}=12)$ who have represented Norway in Olympic Games or World Championships were tested at the Norwegian National Sports Centre in the period 1996-2010 and had an average $\mathrm{VO}_{2 \max }$ of $69 \mathrm{ml} / \mathrm{kg} / \mathrm{min}$, ranging from 64.8 to $78.7 \mathrm{ml} / \mathrm{kg} / \mathrm{min}$ [68]. The former Kenyan record holder, Kipchoge Keino had a $\mathrm{VO}_{2 \max }$ of $84.8 \mathrm{ml} / \mathrm{kg} / \mathrm{min}$ [57]. This value is comparable to former British $10000 \mathrm{~m}$ world record holder Dave Bedford who had a $\mathrm{VO}_{2 \max }$ of $85.0 \mathrm{ml} / \mathrm{kg} / \mathrm{min}$ [3] and former USA record holder Steve Prefontaine who had $84.4 \mathrm{ml} / \mathrm{kg} / \mathrm{min}$ [53]. Other studies have shown $\mathrm{VO}_{2 \max }$ values from 70 to $85 \mathrm{ml} / \mathrm{kg} / \mathrm{min}$ in men and 60 to $75 \mathrm{ml} / \mathrm{kg} / \mathrm{min}$ in women who have competed at an international level in long-distance running $[46,59,62]$.

\section{RUNNING ECONOMY}

Running economy (RE) is defined as the oxygen consumption required for a given submaximal intensity $[1,15,58]$. In the 1930s, Dill et al. [19] found differences in oxygen consumption $\left(\mathrm{VO}_{2}\right)$ at a given speed between runners. Since then a number of studies have reported considerable variation in oxygen uptake at submaximal loads among runners with similar $\mathrm{VO}_{2 \max }[1,28,42]$. With improved RE runners can maintain a higher speed with the same oxygen uptake.

According to Jones [28], the most common way to test $\mathrm{RE}$ is to test the $\mathrm{VO}_{2}$ at a speed of $16 \mathrm{~km} / \mathrm{h}$. To compensate for the lack of air resistance in the laboratory compared to outdoor running, it is recommended to have a treadmill incline of $1 \%$ [30]. At this speed the $\mathrm{VO}_{2}$ of good runners ranges from 45 to $60 \mathrm{ml} / \mathrm{kg} / \mathrm{min}$. When RE is expressed in $\mathrm{ml} / \mathrm{kg} / \mathrm{km}, 200$ is considered 
an average. Values below and above $200 \mathrm{ml} / \mathrm{kg} / \mathrm{km}$ are expressed as good and poor RE, respectively [28].

Weston et al. [70] compared elite runners from East Africa with European elite runners. Running at a speed of $16.1 \mathrm{~km} / \mathrm{h}$, average $\mathrm{VO}_{2}$ was 187.5 and $190 \mathrm{ml} / \mathrm{kg} / \mathrm{km}$ for east African and European runners, respectively.

A study comparing a group of male Spanish long-distance runners with a group of elite long-distance runners from Eritrea [37] found no significant difference in $\mathrm{VO}_{2 \max }$ between the two groups. $\mathrm{RE}$, however, was significantly better among the Eritrean runners. The Eritrean runner who became World Cross Country champion over $12 \mathrm{~km}$ in 2007 , used only $150 \mathrm{ml} / \mathrm{kg} / \mathrm{km}$ when he ran at speeds of 17,19 and $21 \mathrm{~km} / \mathrm{h}$. This is the lowest $\mathrm{VO}_{2}$ reported at these speeds [38].

In a study by Rabadan et al. [54] test-data for Spanish male middle- and long-distance elite runners $(\mathrm{n}=72)$ from 2000 to 2008 are reported and provide the following values for RE. $1500 \mathrm{~m}$ runners $(\mathrm{n}=25): 190.7 \pm 31.7 \mathrm{ml} / \mathrm{kg} / \mathrm{km}$, $5000 \mathrm{~m}$ runners $(\mathrm{n}=20): 219.7 \pm 37.9 \mathrm{ml} / \mathrm{kg} / \mathrm{km}$, and $10000 \mathrm{~m}$ runners $(\mathrm{n}=12): 203.1 \pm 31.5 \mathrm{ml} / \mathrm{kg} / \mathrm{km}$. These runners were tested on a treadmill with a $1 \%$ incline.

Good RE is often reported among experienced long-distance runners who, over time, have run many kilometres per week $[52,68]$. The RE for Paula Radcliffe, the female world record holder for the marathon distance at the time writing, gradually improved from $204 \mathrm{ml} / \mathrm{kg} / \mathrm{km}$ in 1992 to $175 \mathrm{ml} / \mathrm{kg} / \mathrm{km}$ in 2003. RE was tested on the treadmill running at a speed of $16 \mathrm{~km} / \mathrm{h}$ and an incline of $1 \%$ [28]. Her $\mathrm{VO}_{2 \max }$ was relatively stable during this same period. Jones [28] concluded that many years with high training volume had had a positive effect on her RE. He also believed that strength training could have helped to improve RE. In a vertical jump test, she improved from $29 \mathrm{~cm}$ in 1996 to $38 \mathrm{~cm}$ in 2003 . Other studies have also indicated that strength training can improve RE and performance in distance runners $[51,58]$.

Studies have also shown improvements in RE in runners as a result of interval training $[7,22,32]$ and training intensity at the anaerobic threshold [60]. However, some studies did not find any improvement in RE after a period of endurance training $[33,50]$. The reason for this discrepancy might be that these studies took place over too short a period to affect RE. Johnston et al. [27] examined the effect of 10-week strength training on a range of physiological variables. Subjects were endurance trained female runners with no previous experience of strength training. The training resulted in a strength increase of $24 \%$ in exercises involving muscle groups in the upper body, and $34 \%$ for exercises where the legs were used. During the 10-week training 
period there were no changes in body weight, lean body mass, percentage body fat or muscle circumference. The training did not result in any significant increase in $\mathrm{VO}_{2 \max }$, but the $\mathrm{RE}$ at a given submaximal load improved by $4 \%$. The researchers suggested that the increased strength resulted in greater mechanical efficiency and improved recruitment pattern of the motor units.

Practical experience and research indicate that RE is, to some extent, dependent on training intensity [2, 22, 29, 48]. Daniels and Daniels [17] performed a comparative study of middle-distance runners and marathon runners. The purpose was to see if there were differences in RE between the two groups of runners when running at $1500 \mathrm{~m}$ pace and marathon pace. The results showed that marathon runners had better RE than middledistance runners when running at marathon pace. However, at $1500 \mathrm{~m}$ pace $\mathrm{RE}$ was best among the middle-distance runners. Differences in running speed during training and competitions may explain these findings, and underline the importance of training at specific race pace $[2,56]$. This may also be the reason why endurance training with high intensity has been reported to have a positive effect on RE in trained athletes [13, 18, 22, 29, 63]. Sjödin and Svedenhag [61] studied the effect of specific strength endurance and speed training for well-trained distance runners. In addition to their normal training regimen, these runners also included either step jumps in a $400 \mathrm{~m}$ long asphalt hill or sprint training. Step jump where movement speed was lower than in normal running had the best effect on the RE at a speed corresponding to $4: 00 \mathrm{~min} / \mathrm{km}$, while sprint training had the best effect on $\mathrm{RE}$ at a speed of 3:00 $\mathrm{min} / \mathrm{km}$. The runners in the study improved their RE by, on average, $5.1 \%$. Two of the runners who had trained step jumps had a reduced $\mathrm{VO}_{2}$ of $8 \%$ and $12 \%$, respectively, at the speed $4: 00 \mathrm{~min} / \mathrm{km}$. However, a pace of 4:00 $\mathrm{min} / \mathrm{km}$ is much slower than competition pace for all race distances from $3000 \mathrm{~m}$ to the marathon. Male marathon runners at an international level have a race pace of around 3:00 $\mathrm{min} / \mathrm{km}$.

\section{UTILIZATION OF VO 2MAX $\left(\% \mathrm{VO}_{2 \text { MAX }}\right)$}

$\% \mathrm{VO}_{2 \max }$ is the average percentage of $\mathrm{VO}_{2 \max }$ a runner can sustain over a given distance or time $[1,24]$. Due to methodological problems related to testing $\% \mathrm{VO}_{2 \max }$ during competitions, indirect test methods are generally used. The average percentage of $\mathrm{VO}_{2 \max }$ a runner utilizes at vAT during a laboratory test is often used as an indirect expression of $\% \mathrm{VO}_{2 \max }[24,65]$. A close correlation is found between $\% \mathrm{VO}_{2 \max }$ at $\mathrm{vAT}$ and $\% \mathrm{VO}_{2 \max }$ in competitions $[31,65]$. Good distance runners can typically maintain running speed at $\mathrm{VO}_{2 \max }$ for between five and seven minutes $[4,9]$. When the running time 
exceeds seven minutes, $\% \mathrm{VO}_{2 \max }$ declines with increasing race distance and duration [58]. This means that $\% \mathrm{VO}_{2 \max }$ is an important factor in longer races such as half - marathon and marathon [47]. Male elite runners and runners at regional level, running the marathon between 2:05 and 3:00 hours, utilize $85-80 \%$ of $\mathrm{VO}_{2 \max }$ through a marathon, while runners who have a finish time between $3: 25$ and 4:00 hours utilize $70-60 \%$ of their $\mathrm{VO}_{2 \max }[1,59]$.

To achieve good performances in aerobic endurance events, the athlete needs to work as close as possible to $\mathrm{VO}_{2 \max }[9,65]$. Distance runners at a high level of performance often have a high $\% \mathrm{VO}_{2 \max }$ [65]. When running at a speed corresponding to vAT pace, average $\% \mathrm{VO}_{2 \max }$ in Kenyan male distance runners was a little higher for runners who used a training regimen consisting of high training volume compared to runners using a training regime with slightly lower training volume and higher intensity [5]. The utilization of $\mathrm{VO}_{2 \max }$ at vAT for these two groups were $91.8 \pm 2.5 \%(\mathrm{n}=6)$ and $89.0 \pm 1.2 \%(\mathrm{n}=7)$, respectively. Running at $10000 \mathrm{~m}$ pace, the utilization of $\mathrm{VO}_{2 \max }$ for these two groups was $95.7 \pm 1.9 \%$ and $93.7 \pm 1.9 \%$, respectively [5]. Coetzer et al. [11] reported $92 \%$ fractional utilization of $\mathrm{VO}_{2 \max }$ at a velocity corresponding to $10000 \mathrm{~m}$ pace among runners from South Africa. In a Norwegian study [68], it was found that 12 female long-distance runners at national and international level had a mean $\% \mathrm{VO}_{2 \max }$ at vAT of $86.1 \%$ (range 82.1-90.4\%). Among marathon runners of different performance levels, a correlation has been found between $\% \mathrm{VO}_{2 \max }$ at a speed of $15 \mathrm{~km} / \mathrm{h}$ and marathon time $(r=-0.94 ; p<0.05)$ [59]. In homogeneous groups, however, there does not necessarily exist a correlation between $\% \mathrm{VO}_{2 \max }$ and performance $[5,70]$.

\section{RUNNING VELOCITY AT ANAEROBIC THRESHOLD (VAT)}

Although research indicates that lactate production rather delays muscular fatigue than causing it, and that muscular fatigue is caused by factors other than lactate [55], lactate production coincides with muscular fatigue [28, 55]. A strong correlation has been observed between lactate metabolism and performance level in endurance events $[29,39,69]$ and the relationship between lactate levels and workloads is therefore frequently used to identify and predict distance running performance [20,28]. Anaerobic threshold (AT) is often defined as the highest workload during continuous dynamic work, where large muscle groups are used and where there is a balance between production and elimination of lactate $[8,41]$. 
Various criteria and methods have been used to estimate vAT (20), but a correlation between vAT and performance in long-distance running has been consistently observed, regardless of the method used [39, 45, 71]. vAT is a running speed that a well-trained distance runner can sustain for approximately one hour (half marathon pace for elite runners) [8]. Due to various test methods used for testing vAT, it is difficult to specify exact values for vAT matching performance for different distances.

In a Norwegian study [68], it was found that the variables $\mathrm{VO}_{2 \max }, \mathrm{RE}$ and $\% \mathrm{VO}_{2 \max }$ explained $89 \%$ of the variation in vAT among distance runners at national and international level. In this study, $\mathrm{VO}_{2 \max }$ was correlated with vAT for men $(n=22)$. However, amongst the female athletes there was no correlation between vAT and any of the other variables $\left(\mathrm{VO}_{2 \max }, \mathrm{RE}\right.$ and $\left.\% \mathrm{VO}_{2 \max }\right)(\mathrm{n}=12)$. This was due to large individual differences that, to a certain extent, equalized each other.

In the previously mentioned study of 7 female and 13 male elite Kenyan long-distance runners, Billat et al. [5] used a field test on a synthetic $400 \mathrm{~m}$-track to test $\mathrm{VO}_{2 \max }, \mathrm{RE}, \mathrm{vVO}_{2 \max }$ and vAT. The starting speed was set at $14 \mathrm{~km} / \mathrm{h}$ and $16 \mathrm{~km} / \mathrm{h}$ for women and men, respectively. Every $3 \mathrm{~min}$ the speed was increased by $1 \mathrm{~km} / \mathrm{h}$. Between each stage there was $30 \mathrm{~s}$ rest during which a blood sample was taken from the fingertip. Lactate concentration was analysed by Lactate Pro LT analyser. Average vAT for women was $16.8 \pm 0.8 \mathrm{~km} / \mathrm{h}$. Average vAT for the most intensive trained male runners $(\mathrm{n}=6)$ with best average $10000 \mathrm{~m}$ time of $28: 15 \mathrm{~min}( \pm 15 \mathrm{~s})$ was $20.2 \pm 0.4 \mathrm{~km} / \mathrm{h}$. Men $(\mathrm{n}=7)$ who used a training regimen consisting of higher training volume and lower training intensity and with an average best $10000 \mathrm{~m}$ times of $28: 54 \pm 33 \mathrm{~s}$, had an average vAT of $19.9 \pm 0.4 \mathrm{~km} / \mathrm{h}$.

Maffulli et al. [39] reported a correlation between vAT and performance over distances from $5000 \mathrm{~m}$ to the marathon. However, there was no correlation between vAT and performance for $800 \mathrm{~m}$ and $1500 \mathrm{~m}$. This suggests that large volumes of training influence vAT. Jones [28] also reports an increase in vAT for the female marathon world record holder at the time writing, as a result of many years with high training volume. Lehmann et al. [36] reported increased vAT as a result of more training performed at intensities at vAT pace in distance runners. Other studies have reported increased vAT as a result of more training at velocities above vAT pace $[6,66]$. 


\section{SUMMARY}

The research literature indicates that $\mathrm{VO}_{2 \max }$ for distance runners competing at an international level has been between 70 and $87 \mathrm{ml} / \mathrm{kg} / \mathrm{min}$ in men, and between 60 and $78.7 \mathrm{ml} / \mathrm{kg} / \mathrm{min}$ in women, respectively [28, 46, 59, 62, 68].

$\mathrm{RE}$ is often expressed as the $\mathrm{VO}_{2}$ at a speed of $16 \mathrm{~km} / \mathrm{h}$ on a treadmill with $1 \%$ slope [30]. At this speed, the $\mathrm{VO}_{2}$ for good runners range from 45 to $60 \mathrm{ml} / \mathrm{kg} / \mathrm{min}$ [28]. When RE is expressed in $\mathrm{ml} / \mathrm{kg} / \mathrm{km}, 200$ is considered an average. Values below and above 200 are expressed as good and poor RE, respectively [28]. Among elite runners of the same performance level, an inverse relationship has been found between $\mathrm{VO}_{2 \max }$ and $\mathrm{RE}[43,68]$. The average fractional utilization of $\mathrm{VO}_{2 \max }$ at $\mathrm{vAT}$ pace has been reported to be 86.1 and $84.5 \%$ in studies of Norwegian $(n=12)$ [68] and Kenyan $(n=7)$ [5] female elite long-distance runners, respectively. In two groups of Kenyan male elite long-distance runners, average $\% \mathrm{VO}_{2 \max }$ at vAT was 89.0 and $91.8 \%$, respectively [5]. However, the fractional utilization of $\mathrm{VO}_{2 \max }$ was not a factor predicting performance among homogenous groups of Kenyan and Norwegian elite distance runners $[5,68]$. Due to lack of air resistance, laboratory testing of elite runners is recommended to be conducted on treadmill with $1 \%$ slope [30]. Higher vAT and $\mathrm{VO}_{2 \max }$ are reported for longdistance runners than for middle-distance runners [54, 68] even though middle-distance runners typically carry out more intensive training, which has been shown to be beneficial in increasing $\mathrm{VO}_{2 \max }$ in recreational runners [23]. Good RE is also reported among long-distance runners as a result of many years with high training volume (many kilometres per week) [28, 68].

When it comes to the training methods best suited to improving the different variables that influence performance among elite distance runners, a review article by Midgley et al. [40] underlines that much of the current understanding regarding the response to exercise is based on studies of untrained and moderately trained individuals. To use this knowledge to give training recommendations to elite runners is hardly valid. Researchers should therefore exercise caution when giving training recommendations to coaches and elite distance runners based on limited available research.

The training methods used by elite distance runners during the last decades have been influenced by training theories that provided success for other outstanding runners, from trial-and - error of coaches and runners themselves, and, to some extent, also by research. Some athletes and coaches have focused on high intensity training and lower training volume, while others prioritized greater training volume with lower intensity. Still others have combined large training volumes with elements of more intensive training. 
In a recently published review article [67] examining the training volume and intensity distribution of international level distance runners, international level distance runners were found to run an average of 120-260 km/week. The training volume for $5000 \mathrm{~m}$ and $10000 \mathrm{~m}$ runners was typically around $150-200 \mathrm{~km} /$ week, while $1500 \mathrm{~m}$ runners typically ran $120-160 \mathrm{~km} /$ week. High training volume is often a result of many weekly training sessions, and elite runners typically carry out from 12 to 17 running sessions per week. The runners combined these weekly training volumes, of which 70 to $90 \%$ is carried out as easy and moderate continuous running, with 2-4 sessions per week at the velocity at the anaerobic threshold (vAT pace), and 1-2 sessions per week above vAT pace during the preparatory period. Runners who competed over distances from $1500 \mathrm{~m}$ to $10000 \mathrm{~m}$ reduced the number of sessions carried out at vAT pace and increased the number of sessions at specific race pace in the pre-competition period and during the competition period. The best results for the marathon have been achieved using a "low volume/high intensity-model" (150-200 km/week), as well as via a "high volume/low intensity-model" (180-260 km/week).

\section{REFERENCES}

1. Bassett DR, Howley ET. (2000) Limiting factors for maximum oxygen uptake and determinants of endurance performance. Med Sci Sports Exerc, 32(1): 70-84

2. Berg K. (2003) Endurance training and performance in runners. Sports Med, 33(1): 59-73

3. Bergh U. (1982) Physiology of cross-country ski-racing. Campaign, Illinois: Human Kinetics

4. Billat LV. (1996) Use of blood lactate measurements for prediction of exercise performance and for control of training. Recommendations for long-distance running. Sports Med, 22(3): 157-175

5. Billat V, Lepretre PM, Heugas AM, Laurence MH, Salim D, Koralsztein JP. (2003) Training and bioenergetic characteristics in elite male and female Kenyan runners. Med Sci Sports Exerc, 35(2): 297-304

6. Billat V, Sirvent P, Lepretre PM, Koralsztein JP. (2004) Training effect on performance, substrate balance and blood lactate concentration at maximal lactate steady state in master endurance-runners. Pflugers Arch, 447(6): 875-883

7. Billat VL, Flechet B, Petit B, Muriaux G, Koralsztein JP. (1999) Interval training at $\mathrm{VO}_{2 \max }$ effects on aerobic performance and overtraining markers. Med Sci Sports Exerc, 31(1): 156-163

8. Billat VL, Sirvent P, Py G, Koralsztein J-P, Mercier J. (2003) The concept of maximal lactate steady state: a bridge between biochemistry, physiology and sport science. Sports Med, 33(6): 407-426 
9. Bosquet L, Leger L, Legros P. (2002) Methods to determine aerobic endurance. Sports Med, 32(11): 675-700

10. Busso T, Chatagnon M. (2006) Modelling of aerobic and anaerobic energy production in middle-distance running. Eur J Appl Physiol, 97(6): 745-754

11. Coetzer P, Noakes TD, Sanders B, Lamberyt MI, Bosch AN, Wiggins T, Dennis SC. (1993) Superior fatigue resistance of elite black South African distance runners. J Appl Physiol, 75(4): 1822-1827

12. Conley DL, Kranenbuhl GS. (1980) Running economy and distance running performance of highly trained athletes. Med Sci Sports Exerc, 12: 357-360

13. Conley DL, Krahenbuhl GS, Burkett LN, Millar AL. (1984) Following Steve Scott: physiological changes accompanying training. Phys Sportsmed, 12(1): 103-106

14. Costill DL, Higdon H. (1982) A season in Norway: What makes Grete run? The runner, 50-83

15. Costill DL, Thomsen H, Roberts E. (1973) Fractional utilization of the aerobic capacity during distance running. Med Sci Sports, 5: 248-252

16. Coyle EF. (1995) Integration of the physiological factors determining endurance performance ability. Exerc Sport Sci Rev, 23: 25-63

17. Daniels J, Daniels N. (1992) Running economy of elite male and elite female runners. Med Sci Sports Exerc, 24: 483-489

18. Denadai BS, Ortiz MJ, Greco CC, de Mello MT. (2006) Interval training at 95\% and $100 \%$ of the velocity at VO2max: effects on aerobic physiological indexes and running performance. Appl Physiol Nutr Metab, 31(6): 737-743

19. Dill DB, Talbot JH, Edwards HT. (1930) Studies in muscular activity. VI: Response of several individuals to a fixed task. J Appl Physiol, 69: 267-305

20. Faude O, Kindermann W, Meyer T. (2009) Lactate threshold concepts: how valid are they? Sports Med, 39(6): 469-490

21. Foster C. (1983) $\mathrm{VO}_{2 \max }$ and training indices as determination of competitive running performance. J Sports Sc, 1: 13-22

22. Franch J, Madsen K, Djurhuus MS, Pedersen PK. (1998) Improved running economy following intensified training correlates with reduced ventilatory demands. Med Sci Sports Exerc, 30(8): 1250-1256

23. Helgerud J, Hoydal K, Wang E, Karlsen T, Berg P, Bjerkaas M, Simonsen T, Helgesen C, Hjorth N, Bach R, Hoff J. (2007) Aerobic high-intensity intervals improve $\mathrm{VO}_{2 \max }$ more than moderate training. Med Sci Sports Exerc, 39(4): 665-671

24. Impellizzeri FM, Marcora SM, Rampinini E, Mognoni P, Sassi A. (2005) Correlations between physiological variables and performance in high level cross country off road cyclists. Br J Sports Med, 39(10): 747-751

25. Ingham SA, Whyte GP, Pedlar C, Bailey DM, Dunman N, Nevill AM. (2008) Determinants of $800-\mathrm{m}$ and $1500-\mathrm{m}$ running performance using allometric models. Med Sci Sports Exerc, 40(2): 345-350

26. Jacobs I. (1986) Blood lactate. Implications for training and sports performance. Sports Med, 3(1): 10-25 
27. Johnston RE, Quinn TJ, Kertzer R, Vroman NB. (1995) Improving running economy through strength training. Strength Cond J, 17(4): 7-13

28. Jones AM. (2006) The physiology of the world record holder for the women's marathon. Int J Sports Sci Coach, 1(2): 101-116

29. Jones AM, Carter H. (2000) The effect of endurance training on parameters of aerobic fitness. Sports Med, 29(6): 373-386

30. Jones AM, Doust JH. (1996) A 1\% treadmill grade most accurately reflects the energetic cost of outdoor running. J Sports Sci, 14(4): 321-327

31. Joyner MJ. (1991) Modelling: optimal marathon performance on the basis of physiological factors. J Appl Physiol, 70(2): 683-687

32. Laffite LP, Mille-Hamard L, Koralsztein JP, Billat VL. (2003) The effects of interval training on oxygen pulse and performance in supra-threshold runs. Arch Physiol Biochem, 111(3): 202-210

33. Lake MJ, Cavanagh PR. (1996) Six weeks of training does not change running mechanics or improve running economy. Med Sci Sports Exerc, 28(7): 860-869

34. Legaz-Arrese A, Munguia-Izquierdo D, Carranza-Garcia LE, Reverter-Masia J, Torres-Davila CG, Medina-Rodriguez RE. (2011) The validity of incremental exercise testing in discriminating of physiological profiles in elite runners. Acta Physiol Hung, 98(2): 147-156

35. Legaz-Arrese A, Munguia-Izquierdo D, Nuviala AN, Serveto-Galindo O, Urdiales DM, Masia JR. (2007) Average $\mathrm{VO}_{2 \max }$ as a function of running performances on different distances. Sci Sports, 22(1): 43-49

36. Lehmann M, Dickhuth HH, Gendrisch G, Lazar W, Thum M, Kaminski R, Aramendi JF, Peterke E, Wieland W, Keul J. (1991) Training - overtraining. A prospective, experimental study with experienced middle-and long-distance runners. Int J Sports Med, 12(5): 444-452

37. Lucia A, Esteve-Lanao J, Oliván J, Gomez-Gallego F, San Juan AF, Santiago C, Perez M, Chamorro-V. C, Foster C. (2006) Physiological characteristics of the best Eritrean runners-exceptional running economy. Appl Physiol Nutr Metab, 31(5): 530-540

38. Lucia A, Oliván J, Bravo J, Gonzalez-Freire M, Foster C. (2008) The key to top-level endurance running performance: a unique example. Br J Sports Med, 42(3): 172-174

39. Maffulli N, Capasso G, Lancia A. (1991) Anaerobic threshold and performance in middle and long distance running. J Sports Med Phys Fitness, 31(3): 332-338

40. Midgley AW, McNaughton LR, Jones AM. (2007) Training to enhance the physiological determinants of long-distance running performance. Sports Med, 37(10): 857-880

41. Midgley AW, McNaughton LR, Wilkinson M. (2006) Is there an optimal training intensity for enhancing the maximal oxygen uptake of distance runners?: empirical research findings, current opinions, physiological rationale and practical recommendations. Sports Med, 36(2): 117-132 
42. Morgan DW, Craib M. (1992) Physiological aspects of running economy. Med Sci Sports Exerc, 24(4): 456-461

43. Morgan DW, Daniels JT. (1994) Relationship between $\mathrm{VO}_{2 \max }$ and the aerobic demand of running in elite distance runners. Int J Sports Med, 15(7): 426-429

44. Morgan DW, Martin PE, Krahenbuhl GS. (1989) Factors affecting running economy. Sports Med, 7(5): 310-330

45. Nicholson RM, Sleivert GG. (2001) Indices of lactate threshold and their relationship with 10-km running velocity. Med Sci Sports Exerc, 33(2): 339-342

46. Noakes T. (1986) Lore of Running. Cape Town

47. Noakes T. (2001) Physiological capacity of the elite runner. In: Bangsbo J, Larsen HB (eds). Running \& Science-in an interdisciplinary perspective. Copenhagen: Institute of Exercise and Sports Sciences, University of Copenhagen, Munksgaard; $19-47$.

48. Noakes T. (2003) Commentary: training and bioenergetic characteristics in elite male and female Kenyan runners. Med Sci Sports Exerc, 35(2): 305-306

49. Noakes TD, Myburgh KH, Schall R. (1990) Peak treadmill running velocity during the $\mathrm{VO}_{2 \max }$ test predicts running performance. J Sports Sci, 8: 35-45

50. Overend TJ, Paterson DH, Cunningham DA. (1992) The effect of interval and continous training on the aerobic parameters. Can J Sport Sci, 17(2): 129-134

51. Paavolainen L, Hakkinen K, Hamalainen I, Nummela A, Rusko H. (1999) Explosive-strength training improves 5-km running time by improving running economy and muscle power. J Appl Physiol, 86(5): 1527-1533

52. Pate RR, Macera CA, Bailey SP, Bartoli WP, Powell KE. (1992) Physiological, anthropometric, and training correlates of running economy. Med Sci Sports Exerc, 24(10): 1128-1133

53. Pollock ML. (1977) Submaximal and maximal working capacity of elite distance runners. Part 1: cardiorespiratory aspects. In Milvy P. (ed), Marathon: physiological, medical, epidemiological, and psychological studies., New York, New York Academy of Sciences, 4: 310-322

54. Rabadan M, Diaz V, Calderon FJ, Benito PJ, Peinado AB, Maffulli N. (2011) Physiological determinants of speciality of elite middle- and long-distance runners. J Sports Sci, 29(9): 975-982

55. Robergs RA, Ghiasvand F, Parker D. (2004) Biochemistry of exercise-induced metabolic acidosis. Am J Physiol Regul Integr Comp Physiol, 56(3): R502-R516

56. Robinson DM, Robinson SM, Hume PA, Hopkins WG. Training intensity of elite male distance runners. Med Sci Sports Exerc, 23(9): 1078-1082

57. Saltin B, Åstrand PO. (1967) Maximal oxygen uptake in athletes. J Appl Physiol, 23(3): 353-358

58. Saunders PU, Pyne DB, Telford RD, Hawley JA. (2004) Factors affecting running economy in trained distance runners. Sports Med, 34(7): 465-485

59. Sjödin B, Svedenhag J. (1985) Applied physiology of marathon running. Sports Med, 2(2): 83-99 
60. Sjödin B, Jacobs I, Svedenhag J. (1982) Changes in onset of blood lactate accumulation (OBLA) and muscle enzymes after training at OBLA. Eur J Appl Physiol, 49(1): 45-57

61. Sjödin B, Svedenhag J. (1986) Effekten av spesiell styrketrening før medel- och långdistansløpare Rapport från Idrottens forskningsråds konferens på Bosøn 1984.

62. Smith D, Telford R, Peltola E, Tumilty D. (2000) Protocols for the physiological assessment og high-performance runners. In: CJ Gore editor. Physiological tests for elite athletes. Australian Sports Commision, Human Kinetics, Campaign Il, 334-244

63. Smith DJ. (2003) A framework for understanding the training process leading to elite performance. Sports Med, 33(15): 1103-1126

64. Spencer MR, Gastin PB. (2001) Energy system contribution during 200- to 1500-m running in highly trained athletes. Med Sci Sports Exerc, 33(1): 157-162

65. Svedenhag J. (2000) Endurance conditioning. In Shepard RJ, Åstrand PO. (Eds). Endurance in Sport. Oxford: Blackwell

66. Tanaka K, Watanabe H, Konishi Y, Mitsuzono R, Sumida S, Tanaka S, Fukuda T, Nakadomo F. (1986) Longitudinal associations between anaerobic threshold and distance running performance. Eur J Appl Physiol Occup Physiol, 55(3): 248-252

67. Tjelta LI. (2016) The training of international level distance runners. Int J Sports Sci Coach, 11(1): 122-134

68. Tjelta LI, Tjelta AR, Dyrstad SM. (2012) Relationship between velocity at anaerobic threshold and factors affecting velocity at anaerobic threshold in elite distance runners. Int J Appl Sports Sci, 24(1): 8-17

69. Tolfrey K, Hansen SA, Dutton K, McKee T, Jones AM. (2009) Physiological correlates of 2-mile run performance as determined using a novel on-demand treadmill. Appl Physiol Nutr Metab, 34(4): 763-772

70. Weston AR, Mbambo Z, Myburgh KH. (2000) Running economy of African and Caucasian distance runners. Med Sci Sports Exerc, 32(6): 1130-1134

71. Yoshida T, Udo M, Iwai K, Chida M, Ichioka M, Nakadomo F, Yamaguchi T. (1990) Significance of the contribution of aerobic and anaerobic components to several distance running performances in female athletes Eur J Appl Physiol Occup Physiol, 60(4): 249-253

\section{Correspondence to:}

Leif Inge Tjelta

Department of Education and Sports Science

University of Stavanger

N-4036 Stavanger, Norway

Phone: +4751 833523

Fax: +4751833450

E-mail: leif.i.tjelta@uis.no 